\title{
EUROPEAN WAR INFLUENCES UPON AMERICAN INDUSTRY AND LABOR
}

\author{
By Samuel Gompers, \\ President, American Federation of Labor.
}

When men were thinking of international peace, secure in the conviction that there could never be another great war, suddenly all of the countries of western Europe were plunged into the most stupendous conflict the world has ever seen. The spirit of civilization had been brooding over the things of the common life, breathing into them an appreciation of the sacredness of human life. Civilization had been laying wise and skillful hands upon the forces of Nature to make them serve men to promote their well-being and development.

Infinite patience, thought, skill, energy had been busy in the task of finding some new thing to conserve and to glorify humanity. There were minds rich in culture, characters of infinite courage, and hearts tender with love of human beings that counted all gain that brought opportunity into the lives of men-opportunity for physical, mental and moral health and development.

In the midst of all this came the fearful war cry. We of America, far removed from the sound of drums and the march of mobilization, looked at one another and murmured, "It can't be true." Grim realization came as we felt the shock of the revolutionary changes that paralyzed industry.

The stupendous conflict shook to its foundations the structure of organized society. Industry and commerce are organized on a world basis. Markets have international sources of supply and they meet the demands of international buyers. The monetary medium for international exchange is responsive to international influences. The intricate structure of credit extends its gossamer threads about all the markets and ports and bourses of the world. Supply and demand are estimated from a world viewpoint. Communication was organized to meet the needs of world commerce and industry.

When the disrupting forces of war hit the world structure of civilization, then did we in the United States realize the war was a 
reality. Though far away from the bloodshed, from the horror of the maimed and the dead and dying, yet something of the brutalizing spirit of war extended even to our isolated continent.

Through no fault or act of theirs the working people of the United States have been made to feel the consequences of a war caused by the spirit of greed and aggrandizement on the part of irresponsible governmental agents. Autocracy, secret diplomacy, militarism, forced a war which brings grievous wrongs, losses and misery upon the wage workers of Europe-aye, which robs them of life itself - and which indirectly carries suffering and misery to the wage-earners of all the world.

The European war ruthlessly reversed the purposes and ideals of civilization. War is always revolutionary and destructive of life and civilization. The outbreak of this war dislocated American markets and trade.

The first stage following the cataclysmic struggle was one of stagnation. Business men, government officials, scientists, commercial and industrial associations considered carefully the conditions confronting them and estimated their needs and resources. The way problems have been solved and new opportunities utilized proves that Americans have qualities of adaptability and resourcefulness assuring continuous progress.

Necessity forces invention. American ingenuity and enterprise have not failed in this time of need. American industries find they can supply many of their needs and have found uses for what was formerly industrial waste. The war has opened up tremendous economic opportunities-some temporary, others permanent. After the first reaction came an industrial impetus. Business reached after new opportunities. American financial genius protected our interests and made this the world's money center.

What has been done to meet industrial and financial emergencies and needs has been due chiefly to private initiative and private enterprise. It is the American characteristic - ability to do thingsthat has served us in this time of need. That American spirit of self-reliance and initiative is the most precious possession of the nation. It is the spirit that can dream and dare and achieve. It is invincible.

Now turn to the human side of adjustment to war conditions. Have the men and women employed in industry and commerce been 
as carefully and wisely provided for as material interests have been?

The first shock of the war which brought stagnation to industry resulted in the closing of shops, mills and docks, and meant unemployment for wage-earners. All along the Atlantic coast industry and commerce were dislocated; shipping was tied up; men found that the war had taken away their work, their source of livelihood. Their number was increased by the sailors from interned foreign vessels. Factories dependent upon European trade or products began to run part time and then stopped. During the period of readjustment many workers were without the means of earning their daily bread and they had but little laid aside. At the same time they were threatened with the menace of war prices. Six cent bread meant tragedy to east side New York and similar localities where wage-earners live. The brutalizing spirit of war laid hands on American industry-workers were deprived of employment and were exploited by war prices which meant unwarrantable and exclusive advantages to the profit mongers.

As the weeks went by the amount and extent of unemployment increased throughout the country. Unemployment means to most of you here an industrial and social problem - to the wageearner it is a personal experience. It means hunger, misery and despair. Bread lines have been very long during the past winter. Women as well as men have been in these bread lines. A bread line leaves an indelible scar on the hearts of those who have undergone the humilation. It means that a human soul has been beaten in the struggle for decent self-respect.

Constructive efforts to meet this human need came from the workers. Wage-earners are so close to the raw stuff of the experiences of the common struggle for a livelihood that they appreciate more keenly the meaning of unemployment and they know that their own well-being is very intimately involved. Unemployment in some callings means increasing the supply of available workers for many others. Organized workers are a power which can and does say to heartless greed for profits-Stop your brutality. Those wage-earners who were organized were able to take care of themselves and to maintain American standards of living. Again as in the last financial crisis they raised the slogan, "No wage reductions," and warded off the policy whose cumulative effect would have shaken the whole 
economic structure. A policy of wage reductions would have destroyed confidence and hence would have undermined credit.

Through their economic organization organized workers had the means by which they could make adjustments necessary to protect human interests from impending perils. Those who are unable to defend themselves are always made to bear the brunt of hardships. Organization is the method by which the workers can protect themselves from being made the burden bearers in all calamities and can secure an equitable participation in prosperity. In all cases it is power for self-protection that is their safeguard. The constructive efforts made to help the workers during this emergency were made by the labor organizations. As I said before, they stood solidly for maintenance of wages which meant maintenance of American standards of living and checking the diminution of purchasing power.

The constructive power that protects the workers in war time is the same power that protects them in peace. The economic organizations were the agencies that enabled them to cope with unemployment and to relieve in some measure the distress caused by the war. Through trade organizations the workers are coöperating with responsible national, state and municipal authorities to meet emergencies while at the same time safeguarding the workers from exploitation which naturally results from the ruthless, brutal spirit which war engenders.

The labor movement of the world is the one agency whose members have been loyal to fatheriands in the time of peril and yet have with insistent emphasis and appeal upheld the sacredness of human life and opportunity and the brotherhood of man. While bearing burdens of the war they are still maintaining standards that dignify human life and are creating and directing influences that will have an important part in establishing peace and the constructive work which shall make for greater justice in international relations.

The United States as well as the whole world has suffered through the disrupting influence of the war. In the United States the organized labor movement has dealt constructively with the needs and the emergencies created by the war.

Where production was decreased, wherever possible they provided that work should be equally shared, that those of their trade should not be added to the number of the unemployed. Through 
their trade benefits they helped fellow workers who were out of work, while the trade organization assisted them in finding employment. The trade union movement acted as a steadying force to all industry by steadily and determinedly opposing irrational, erratic changes.

Organized labor furthermore made demands upon municipalities and all government authorities that public construction work should be continued where contracts had been let and that beneficent new work should at once be undertaken wherever possible.

The organized workers were alert to opportunities, aware of their own interests, able to protect themselves and those dependent upon them. They manifest the American characteristics, resourcefulness and adaptability that enabled us all to weather the difficulties resulting from the war. We have fostered and developed the spirit of self-reliance and initiative necessary to national life.

The workers upon whom war burdens have fallen most heavily have been the unorganized. Their suffering has been inarticulate, helpless misery. They were without the means of expressing their misery or their needs. They have benefited indirectly from the efforts of organized labor but that did not relieve them of the heavy weight of the burdens of the industrial crisis.

The army of the unemployed has been made up largely from the ranks of the unskilled workers. It is a well known policy of large corporations employing unskilled workers to have available a greater number of workers than they regularly employ. This condition is a menace to steady employment. It is intended not only to discourage efforts of workers to secure higher wages or better conditions of work, but is also used as an instrument to enforce lower standards. Where there are two or three waiting for a job it takes more than human courage to make a stand for rights - the workers have to think each day of daily bread for the next day. To stop work means to go without food.

This condition is largely the result of superinduced immigration. Shipping companies and big employers of unskilled workers have stood for a policy of unrestricted immigration. For many years that policy did little harm, but now the frontier opportunity has ceased to exist and the number and the character of the immigrants are such that they can no longer be assimilated by the American nation. Some restrictive policy must be adopted. 
In addition to a situation already grave, our nation must face after-war consequences. There is no doubt but that the war will be followed by a tide of emigration of unparalleled proportions. The countries that are now engaged in the bloody struggle will seek some way to escape caring for derelicts of war, the mental and physical wrecks and those who have been ruined financially. The incompetent and those who probably may become a burden upon the community will be encouraged and perhaps assisted to emigrate.

You have only to turn to our southern border line for verification of this assertion. Responsible authority informs me that Mexican military authorities have been furnishing free transportation and otherwise encouraging the emigration of dependent women and children, and the men who are unfit for service in the army or unable to work.

What is taking place on the southern border is a very insignificant reminder of what will happen at the close of the European war. Now is the time to make provisions against that impending disaster.

The end of the war will bring to our country another economic reaction. Those industries that have been stimulated because of a demand created by the war will come upon a period of idleness. New industries that have been developed to supply articles which Europe furnished us before the war will have to meet competition. There will follow in our country a period of readjustment. Again the burdens of that transition will fall most heavily upon the workers, particularly the unorganized workers. Organized workers in the main will be in a position to protect themselves through agreements with employers. The unorganized will be without the means of meeting the difficulties.

The power of the workers to protect themselves is of tremendous importance to the nation-it means to protect the bone and sinews of the nation; to conserve the men and women who do the work necessary to the nation's life; to maintain unimpaired the standards and ideals of American free men.

The lesson of the European war as it affects the American wage-earners demonstrates again the value of the labor movement to a democratic people. It is the way by which the great masses of the nation can think out their industrial problems and order their own lives. 
The labor movement has also its social and political influence that will aid in establishing justice at the end of the war. It will be the greatest force opposing reaction that always results from the brutalizing influences of war. It will be the most potent force to compel relations that shall subordinate all else to human welfare.

When the wage-earners refuse to bear the consequences of deeds and policies for which they are in no way responsible then will those in authority consider more carefully, before they start into activity, forces whose evil consequences will bring hardships and suffering. The working people are more clearly conscious of the extent and the nature of their power than ever before, hence they are in a position to secure for themselves increasing recognition in determining the affairs of industry and of international relations. The wageearners will, I am sure, make their power felt.

In addition to the industrial and commercial issues that the war has raised, the working people of the world are concerned as to what shall be determined with regard to the evil forces that are largely responsible for the war-autocracy and militarism. Through their organized economic power the wage-earners exert a tremendous power in political affairs as well as in industrial and commercial, and they propose to see to it, through their international economic organizations, that democracy shall be assured control in international affairs.

Democracy must be established and endowedd with power and authority. That can be done without militarism. Militarism must fall through gradual disarmament.

Democracy will be maintained by able, free citizens alert to discern their own rights and to distinguish the right, able and willing to maintain justice for all.

When democracy shall have established justice in international relations, then shall the wage-earners of every land have greater opportunities to give their ideals reality in everyday life and dream and plan greater things for all mankind. They will no longer be unresisting pawns for war slaughter or the less spectacular slaughter of industry and commerce. In every relation of life organized labor will establish the principle of the sacredness of human life and will not only oppose the brutalities and the waste of war, but also of peace. 